\title{
Olfactory Bulbectomy in Methamphetamine-Treated Rat Mothers Induces Impairment in Somatic and Functional Development of Their Offspring
}

\author{
R. ŠLAMBEROVÁ ${ }^{1}$, J. RUDÁ-KUČEROVÁ ${ }^{2}$ Z. BABINSKÁ ${ }^{2}$, M. ŠEVČÍKOVÁ ${ }^{1}$ \\ ${ }^{1}$ Department of Normal, Pathological and Clinical Physiology, Third Faculty of Medicine, Charles \\ University, Prague, Czech Republic, ${ }^{2}$ Department of Pharmacology, Faculty of Medicine, Masaryk \\ University, Brno, Czech Republic
}

Received April 10, 2017

Accepted October 25, 2017

\section{Summary}

Olfactory bulbectomy in rodents is considered a putative model of depression. Depression is often associated with drug addiction. Our previous studies demonstrated that methamphetamine (MA) administration to rat mothers affects both, mothers and their pups. The aim of the present study was to examine the effect of bulbectomy, as a model of depression, and MA administration on behavior of rat mothers and postnatal development of their pups. Adult female Wistar rats were randomly divided into two groups: bulbectomized (OBX) and sham-operated (SH). A period of 20 days was allowed for the development of the depressive-like phenotype. Animals were tested in the motor activity test and $2 \%$ sucrose preference for anhedonia and hyperactive locomotor response to a novel environment, respectively. After then females were impregnated. Pregnant females were exposed to daily subcutaneous (s.c.) injection of MA $(5 \mathrm{mg} / \mathrm{kg})$ or saline (SA) during the entire gestation period. Postnatally, maternal behavior and pup development was examined. The effect of a challenge dose of MA (1 mg/kg, s.c.) on behavior was further examined in adult male offspring. Our results showed no differences in the maternal behavior as a matter of bulbectomy, only OBX rats slept more than all the SH controls. Pups from OBX mothers were born with lower birthweight and gained less weight during the postnatal development than pups from SH controls. Both, bulbectomy and MA administration, delayed the eyes opening. As a matter of functional development of the pups, maternal OBX procedure impaired the performance in the Bar-holding test, but only in saline group. OBX/SA group was the worst in the Bar-holding test relative to all the other groups. In addition, pups from OBX mothers dropped more boluses during the Bar-holding test, suggesting that they were more stressed. In adult male offspring, bulbectomy increased immobility only in the SA/SA group. Prenatal MA exposure increased locomotion, while decreasing immobility. In addition, challenge dose of MA in adulthood increased distance traveled, locomotion, rearing, and average and maximal velocity, while decreasing immobility and grooming. In conclusion, our results suggest that depressive-like phenotype of rat mothers induces impairment in somatic and functional development of their male offspring.

\section{Key words}

Methamphetamine - Olfactory bulbectomy - Depression • Maternal behavior $\bullet$ Development

\section{Corresponding author}

R. Šlamberová, Department of Normal, Pathological and Clinical Physiology, Third Faculty of Medicine, Charles University, Ke Karlovu 4, 12000 Praha 2, Czech Republic, Fax: +420 224902 750. E-mail: romana.slamberova@If3.cuni.cz

\section{Introduction}

Clinical studies demonstrated that depression may often result in drug or alcohol addiction and the opposite way around. The comorbidity between addiction and depression varies by the type of abused drugs, the rates of depression reaching $54 \%$ in opioid-dependent, $38 \%$ in alcohol-dependent, and $32 \%$ in psychostimulantdependent patients compared with only $7 \%$ in the whole population (Filip et al. 2013, Kosten et al. 1998). Co-occurrence of substance or alcohol abuse and depression results in even greater disease burdens than 
the separate disorders (Riper et al. 2014). Some of the burdens experienced by people with this comorbidity result in higher mortality levels, functional impairment and increased suicide risk (Riper et al. 2014).

As far as the neurobiology of such comorbidity is concerned, different mechanisms may be involved. Depression resulting in drug abuse may reflect an attempt to self-medicate a depression state, while drug abuse followed by depression may result from an early exposure to chronic drugs of abuse, which leads to neurobiological changes increasing the risk of depression (Filip et al. 2013, Volkow 2004). The Self-medication hypothesis (Hall and Queener 2007, Khantzian 2013) indicates that monoaminergic deficit present in depression may be relieved by the drug of abuse, thus individuals with depression have aberrant brain reward systems and may turn to drugs that create euphoric feelings to compensate for their anhedonia and motivational inadequacy (Baicy et al. 2005, Markou et al. 1998). In addition, experimental studies demonstrated that the rewarding activities of psychostimulant drugs are modified in experimental models of depression and that depression-like effects are observed in animals withdrawn from chronic treatment with psychostimulants such as methamphetamine (MA) and other drugs (Filip et al. 2013, McKernan et al. 2015, McKetin et al. 2011).

Results of preclinical studies examining drug addiction behaviors in animal models are generally conformable with the clinical experience. Bilateral olfactory bulbectomy (OBX) has become the most commonly used model of depression for study of the dual disorder (Kelly et al. 1997, Morales-Medina 2017, Song and Leonard 2005). In this model bulbectomized animals showed a significantly higher vulnerability in intravenous drug self-administration of MA (Kučerová et al. 2012) and also an increased tendency to reinstate the MA-seeking behavior after abstinence (Babinská et al. 2016). Furthermore, other drugs, specifically cannabinoid receptor-1 synthetic agonist (Amchová et al. 2014) and ketamine (Babinská and Rudá-Kučerová 2017) showed similar results. Therefore, it seems that this rat model has a high translational validity and is relevant for the study of neurochemical mechanisms underlying the depression and addiction comorbidity.

Maternal depression in humans is associated with impaired neurodevelopment in newborns (Smith et al. 2012). Rodent studies are in line with this evidence as OBX was previously shown to impair several components of maternal behavior in rats (Schwartz and Rowe 1976) and mice (Neckers et al. 1975). The rodent mothers spend less time nursing the pups and there were also more pups killed by the mother in mice. In rats these effects were reversed by apomorphine treatment suggesting at least an important role of hypodopaminergic state in the OBX model (Sato et al. 2010). The basal hypodopaminergic tone was confirmed in the OBX male rats (Rudá-Kučerová et al. 2015). Therefore, OBX procedure in rat mothers should induce early life stress in the offspring due to maternal behavior deficits which may lead to behavioral changes in adulthood. Dopaminergic system is affected not only by OBX, but also by psychostimulant drugs, such as MA (Rothman and Baumann 2006).

Psychostimulants act via dopaminergic, noradrenergic and serotonergic systems, though, the degree of effect of each drug differs between specific neurotransmitters (Rothman and Baumann 2006). Also MA is consistently reported to have detrimental developmental effects in human (Wouldes et al. 2014) as well as in laboratory animals (Malinová-Ševčíková et al. 2014, McDonnell-Dowling and Kelly 2015, Šlamberová 2012). Our previous studies demonstrated that MA exposure during gestation impairs maternal behavior of rat mothers (Šlamberová et al. 2005) and delays sensorimotor development of their pups (Šlamberová et al. 2006). A recent clinical study evaluated the neurodevelopmental effects of prenatal MA exposure and maternal depression and identified deficits in infants in either group. However, the combination of drug exposure and maternal depression did not lead to increased risks (Smith et al. 2012). To the best of our knowledge, there is no experimental study attempting a downwards translation of this situation to an animal model which could provide more information on the underlying mechanisms.

Therefore, the aim of this study was to extent our knowledge on the animals modelling of comorbid depression and addiction by evaluating developmental effects of combined MA exposure and depressive-like phenotype of the rat mothers induced by OBX. We hypothesized a differential behavioral profile and altered reactivity to MA in the offspring of the OBX mothers.

\section{Methods}

Adult female and male albino Wistar rats $(375-400$ g) provided by Charles River Laboratories 
International, Inc. were delivered by VELAZ (Prague, Czech Republic). Animals were housed four per cage by sex and left undisturbed for a week in a temperaturecontrolled $\left(22-24{ }^{\circ} \mathrm{C}\right)$ colony room with free access to food and water on a $12 \mathrm{~h}$ (light):12 h (dark) cycle with lights on at 06:00 h.

\section{Olfactory bulbectomy}

At the beginning of the behavioral and neurochemical experiments, rats were randomly divided into two groups: bulbectomized (OBX, n=13) and shamoperated $(\mathrm{SH}, \mathrm{n}=9)$ rats and the surgery was performed as described earlier (Kučerová et al. 2012). Animals were anaesthetized with i.p. injections of $50 \mathrm{mg} / \mathrm{kg}$ ketamine plus $8 \mathrm{mg} / \mathrm{kg}$ xylazine. The top of the skull was shaved and swabbed with an antiseptic solution. Then, midline frontal incision was made on the skull and the skin was retracted bilaterally. Two burr holes, $1.5 \mathrm{~mm}$ in diameter, were drilled in the frontal bone $7.5 \mathrm{~mm}$ anterior and $2 \mathrm{~mm}$ lateral to bregma suture. Both olfactory bulbs were removed by aspiration paying particular attention to not damage the frontal cortex. Prevention of blood loss from the ablation cavity was achieved by filling the dead space with a hemostatic sponge. The skin above the lesion was closed with suture. Finally, bacitracin plus neomycin dusting powder was applied to prevent bacterial infection. During the surgery, two animals were killed to check whether the bulbs were removed entirely. All OBX rats were dissected at the end of the study in order to verify the OBX surgery.

Sham-operated rats underwent identical anesthetic and drilling procedures but their bulbs were left intact. A period of at least 20 days was allowed for the recovery from the surgical procedure and the development of the depressive-like phenotype. During this period, animals were handled daily for few minutes to eliminate aggressiveness (Kelly et al. 1997). Animals were then tested in the LABORAS apparatus for potential hyperactive locomotor response to a novel environment and in the $2 \%$ sucrose preference test to assess potential anhedonia.

\section{Spontaneous activity}

After the 20-day post-surgical brake the spontaneous activity was tested in a LABORAS apparatus (Metris B.V., Netherlands) situated in a dark room. The LABORAS (Laboratory Animal Behavior Observation Registration and Analysis System) is a fully automated system for continuous behavior recognition and tracking in small rodents as described in our study (Schutová et al. 2013). Animals were tested in the unknown environment for $10 \mathrm{~min}$. The 10 -minute period was divided to ten minute measures (Intervals) to see the progress of the activity. The following parameters were automatically evaluated in the LABORAS: (1) time spent in locomotion [s]; (2) time spent rearing (exploratory behavior) [s]; (3) distance (trajectory length) [m]; and (4) average speed [ $\mathrm{mm} / \mathrm{min}]$.

\section{Sucrose preference test}

After recovery from the OBX surgery and testing in the LABORAS apparatus, female rats were transferred into single housing with free access to food and water. A two-bottle choice procedure was used to determine their sucrose intake. During the 24-h training phase, each rat was provided in their home cage with two water bottles to adapt rats drinking from two bottles. After training, one bottle was randomly (left or right) switched to contain $2 \%$ sucrose solution. The side of sucrose presentation in the home cage was counterbalanced across rats. At $4 \mathrm{~h}$ and $24 \mathrm{~h}$ time intervals both bottles were removed and the amount of liquid remaining in each bottle was measured. After $4 \mathrm{~h}$, the relative position of the bottles was inverted, i.e. they were switched from one side of the cage to the other to avoid perseveration effects. The sucrose preference score was calculated as the percentage of sucrose solution ingested relative to the total amount of liquid consumed as determined before and after each test, i.e. sucrose preference $=$ sucrose intake $/$ total liquid (sucrose + water) intake x 100 (Amchova et al. 2014).

\section{Drug administration}

After the recovery period and the behavioral tests females were impregnated with sexually mature males as described in our previous study (Šlamberová et al. 2005). Pregnant females (OBX or SH) were exposed to daily subcutaneous (s.c.) injection of MA $(5 \mathrm{mg} / \mathrm{kg})$ or saline (SA) during the entire gestation period (gestational day (GD) 1-22). Females were kept in group cages (4-5/cage) until GD 21. Then they were moved to maternity cages ( 1 female/cage). The day of the delivery was indexed as postnatal day (PD) 0. On PD 1, pups were weighed and the number of males and females were recorded. Maternal behavior was tested in two types of tests: Observation test and Retrieval test. At this time of the study, some OBX rats were lost due to surgery and some did not deliver, therefore, the final numbers of 
mothers in each groups were the following: SH-SA $n=4$, SH-MA $n=5$, OBX-SA $n=4$ and OBX-MA $n=4$.

\section{Maternal behavior - Observation test}

Maternal behavior was observed daily for $50 \mathrm{~min}$ in the home cage of each mother and her litter between PD 1 and PD 22. The time of observation was during the light phase of the light/dark cycle between 08:00 - 09:00 h. Similar methods were used as in our previous studies (Ševčíková et al. 2017, Šlamberová et al. 2005). During each 50-minute session, each mother and her litter were observed 10 times for $5 \mathrm{~s}$ at $5 \mathrm{~min}$ intervals. Eleven types of maternal (mother in or out of the nest; mother in contact with any of her pups; mother licking or grooming any of her pups; mother carrying pups; mother manipulating nest shavings) and non-maternal (mother resting with eyes closed; mother eating; mother drinking; mother self-grooming; mother rearing; mother sniffing with head raised) activities exhibited by the mothers and three nursing positions (arched-nursing; blanket-nursing; passive-nursing) were recorded during each session. Thus, each mother and litter was observed 220 times (22 days x 10 observations / session). During each observation "1" was given if a behavior occurred and a " 0 " if it did not.

The occurrence of each activity (maximum 10 in each session) was counted in each of 22 sessions.

\section{Maternal behavior - Retrieval test}

The same mothers and pups were tested for Retrieval test always after the Observation test ended. The retrieval test was conducted daily between PD 1 and PD 12 between 09:00 - 10:00 h, so each mother and litter was tested 12 times. The same method was used as in our previous studies (Ševčíková et al. 2017, Šlamberová et al. 2005).

All pups were removed from their mothers and placed in a separate cage for $5 \mathrm{~min}$. After this brief separation, the entire litter was returned to their mothers into the maternity cage and the pups were spread all around the cage. The mother was then observed for $10 \mathrm{~min}$, and the following measures were recorded; 1) the latency to carry the first pup, 2) the latency to return the first pup into the nest, 3) the latency to return all the pups into the nest. During each observation "1" was given if a behavior occurred and a "0" if it did not. It was also noted, whether the mother carried first one of her own pup or one of the adopted pup into the nest.

\section{Pup development}

To examine pup's somatic and functional development, the same methods were used as in our previous studies (Malinová-Ševčíková et al. 2014, Ševčíková et al. 2017). The final groups of tested pups were as follows: SH-SA males $(n=24)$, SH-SA females $(n=23)$, SH-MA males $(n=24)$, SH-MA females $(n=23)$, OBX-SA males $(n=14)$, OBX-SA females $(n=15)$, OBX-MA males ( $\mathrm{n}=15)$, OBX-MA females $(\mathrm{n}=15)$.

\section{Litter characteristics and maturation of the pups}

The same method was used as in our previous study (Ševčíková et al. 2017). Number of pups in the litter, number of dead pups, and percentage of males and females in each litter was recorded and compared between groups. Pups were weighted daily between PD 1 and 23 and the day of eye opening was recorded as a number of pups with eyes opened on PD 14 and PD 15.

\section{Negative Geotaxis}

Negative geotaxis was tested on PD 9 (Altman and Sudarshan 1975). Each pup was placed facing downward on a screen inclined at $30^{\circ}$ angle. Each animal was given three trials and the best latency of turning the face upward $\left(180^{\circ}\right.$ rotation) was recorded. If the pup was slid off the board, it was replaced in the downward position.

\section{Righting reflex on surface}

Righting reflex on surface was tested on PD 12 (Altman and Sudarshan 1975). Each pup was turned on its back, and the time it took for the pup to right with all four paws contacting the surface of the testing table was recorded. If righting did not occur within $60 \mathrm{~s}$ period, the test was terminated and a time of $60 \mathrm{~s}$ was given for that trial.

\section{Righting reflex in mid-air}

The righting reflex in mid-air (Altman and Sudarshan 1975) was tested on PD 17. Each pup was held on its back $40 \mathrm{~cm}$ above the soft pad and then released and watched in which position it reaches the soft pad. A score of "1" was given when a pup reached the ground at once with all 4 paws and a "0" when it did not.

\section{Bar-holding test}

The beam balance test on PD 23 was used to examine vestibular function and sensorimotor coordination engaged in maintenance of the balance on 
the narrow bar (Malinová-Ševčíková et al. 2014, Murphy et al. 1995). A wooden bar $40 \mathrm{~cm}$ long with a diameter of $1 \mathrm{~cm}$ was suspended $80 \mathrm{~cm}$ above padded soft surface. The pup was placed on the bar being held by the nape of its neck and its forepaws were allowed to touch the bar. Time of fore- and hindlimb grasping reflex was recorded with a limit of $120 \mathrm{~s}$. Rats were subjected to three consecutive trials.

\section{Rotarod}

Rotarod performance was examined on PD 23 to test the sensorimotor coordination and dynamic postural reactions necessary for active moving to maintain the balance on the rotating cylinder (Gerald and Gupta 1977). Pups were positioned on a rugged cylinder $(11.5 \mathrm{~cm}$ in diameter, rotating at constant speed of $6 \mathrm{rpm}$ ) in the opposite direction of cylinder rotation, so they were able to walk forward. The duration of balance on the rotarod was determined for $120 \mathrm{~s}$. Rats were subjected to maximum 6 trials until successfully accomplished the task. Number of falls was recorded.

\section{Behavior of adult male offspring}

For this part of the study only male offspring were used. The number of rats per group was $n=8$. The effect of challenge dose of MA (1 mg/kg, s.c.) on behavior in the LABORAS apparatus was further examined in adult offspring males prenatally exposed to drug and bulbectomy. Unlike the mothers (see above) male offspring were tested in the LABORAS apparatus for $60 \mathrm{~min}$ to see their habituation. The animals were not habituated to the apparatus before. Each rat was injected with MA $(1 \mathrm{mg} / \mathrm{kg})$ or saline $(1 \mathrm{ml} / \mathrm{kg})$ and immediately placed in the center of the LABORAS cage. The behavior was recorded for $1 \mathrm{~h}$ (Schutová et al. 2013). The 60-minute period was divided to ten 10-minute measures (Intervals) to see the progress of the activity.

The following parameters were automatically evaluated: (1) distance travelled (trajectory length) [m]; (2) time spent in locomotion (horizontal movement in cage) $[\mathrm{s}]$; (3) velocity (average speed) $[\mathrm{cm} / \mathrm{s}]$; and (4) time spent rearing (vertical movement in cage; exploratory behavior) $[\mathrm{s}]$.

\section{Statistical analyses}

In the mothers, spontaneous activity, sucrose preference, observation test (22 days) data were analyzed by a one-way ANOVA (surgery) with Repeated Measure (10 min of testing). Latencies in the retrieval test were analyzed by one-way ANOVA (drug treatment) with Repeated Measure (12 days of testing). The incidence whether the mother carried one of her own or an adopted pup first to the nest was analyzed by $\chi^{2}$ test. Differences were considered significant if $\mathrm{p}<0.05$.

Litter characteristics (number of pups in each litter, the number of dead pups and the percentage of males and females in each litter) data were analyzed by a two-way ANOVA (surgery $\mathrm{x}$ drug exposure). A three-way ANOVA (surgery $x$ drug exposure $x$ sex) was used to analyze differences in birth weight and weight gain during PD 1-22. A $\chi^{2}$ test was used to test eye opening in specific postnatal days. For the analysis of neonatal reflexes a three-way ANOVA (surgery $\mathrm{x}$ drug exposure $\mathrm{x}$ sex) was used. A $\chi^{2}$ test was used for statistical analysis of the righting reflex in mid-air in specific days.

Behavioral test performed at adulthood were analyzed by a three-way ANOVA (surgery x prenatal drug $x$ challenge drug) with Repeated Measure (10 min of testing).

For post hoc comparison a Tukey HSD test was used in all the Analysis of Variance measures. Differences were considered significant if $\mathrm{p}<0.05$ in all analyses.

\section{Results}

Spontaneous activity of OBX females

Bulbectomy increased locomotion

$\left[\mathrm{F}_{(1,15)}=4.51 ; \quad \mathrm{p}<0.05\right]$ and decreased immobility $\left[F_{(1,15)}=10.95 ; p<0.01\right]$ of adult female rats (Fig. 1). Other measures such as distance traveled, velocity and rearing was not influenced by bulbectomy.

\section{Sucrose preference test}

There were no differences in the test of sucrose preference. All groups reached high preference of the sucrose solution.

\section{Maternal behavior}

In the observation test, there were no differences in the type of nursing or other maternal activities. The only difference induced by bulbectomy was increased sleeping $\left[\mathrm{F}_{(1,13)}=5.94 ; \mathrm{p}<0.05\right]$, which seems to correspond with depressive-like behavior. There were no significant differences between groups in the Retrieval test either. 

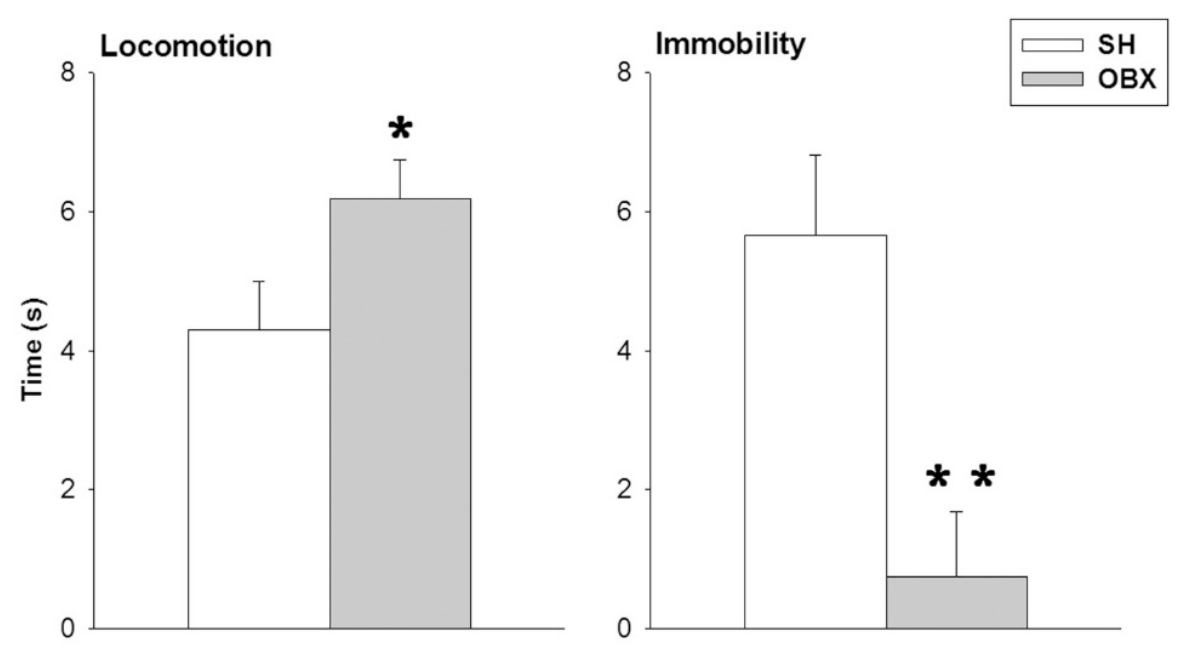

Fig. 1. The effect of bulbectomy on locomotion and immobility of adult female rats tested in the LABORAS apparatus. $\mathrm{SH}=$ sham, $\mathrm{OBX}=$ bulbectomy. Values are mean \pm SEM $(\mathrm{n}=8-9) ; * \mathrm{p}<0.05, * * \mathrm{p}<0.01$ vs. sham-operated controls.

\section{Pup development}

\section{Somatic development}

Pups from OBX mothers were born with lower birthweight $\left[\mathrm{F}_{(1,145)}=5.50 ; \mathrm{p}<0.05\right]$ and gained less weight during the postnatal development $\left[\mathrm{F}_{(1,145)}=13.72\right.$; $\mathrm{p}<0.001]$ that pups from sham controls regardless of prenatal drug exposure. There were sex differences in the birth weight as expected: females had lower birthweight $\left[\mathrm{F}_{(1,145)}=13.91 ; \mathrm{p}<0.001\right]$ than males.

Pups from sham-operated and saline-treated mothers (SH/SA) regardless of their sex opened eyes earlier than all the other groups (on PD $14\left[\chi^{2}=63.48\right.$; $\mathrm{p}<0.0001]$, on PD $\left.15\left[\chi^{2}=53.80 ; \mathrm{p}<0.0001\right]\right)$. Table 1 shows the percentage of animals with eyes opened on PD 14 and PD 15. These results suggest that both, the bulbectomy and MA administration, prolonged the eyes opening.

\section{Functional development}

Bulbectomy impaired the performance in the Bar-holding test (PD 23), but only in saline group. Pups from OBX mothers treated with saline during gestation (OBX/SA) was the worst in the Bar-holding test relative to all the other groups $\left[\mathrm{F}_{(1,145)}=17.15 ; \mathrm{p}<0.0001\right]$ (Fig. 2). In addition, pups from OBX mothers dropped more boluses during the Bar-holding test $\left[\mathrm{F}_{(1,145)}=4.82\right.$; $\mathrm{p}<0.05]$, suggesting that they were more stressed.

In Negative geotaxis (PD 9), Righting reflex on surface (PD 12), Righting reflex in mid-air (PD 17) and Rotarod test (PD 23), there were no differences induced by bulbectomy. Only MA decreased performance in the Rotarod test $\left[\mathrm{F}_{(1,145)}=4.17 ; \mathrm{p}<0.05\right]$ regardless of bulbectomy or sex.

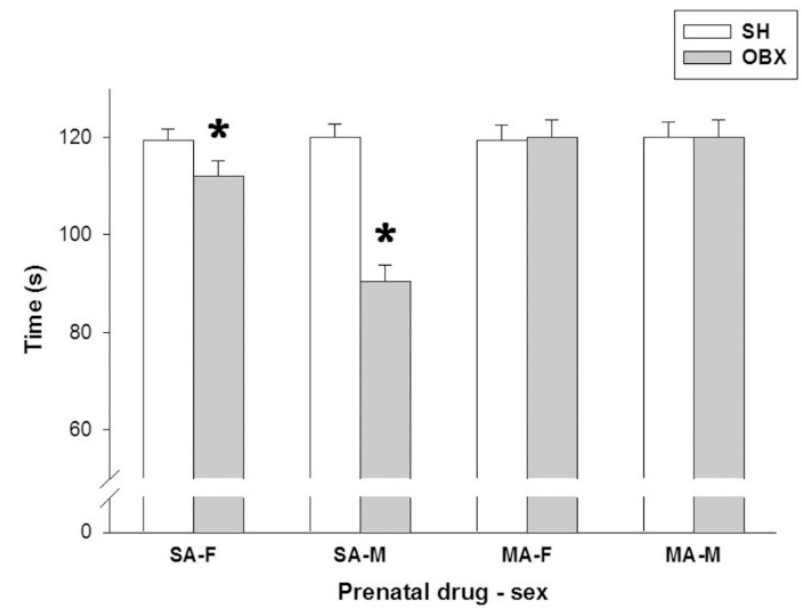

Fig. 2. The effect of maternal bulbectomy on performance of pups in Bar-holding test on PD 23. SH = sham, OBX = bulbectomy. $\mathrm{SA}=$ prenatal saline, $\mathrm{MA}=$ prenatal methamphetamine, $F=$ female, $M=$ male. Values are mean \pm SEM $(n=14-24) ;$ $* p<0.05$ sham-operated controls.

\section{Behavior of adult male offspring}

Bulbectomy increased immobility in prenatally saline-exposed adult males rats injected prior to the test with single saline injection $(\mathrm{SA} / \mathrm{SA})\left[\mathrm{F}_{(1,56)}=4.07 ; \mathrm{p}<0.05\right]$ (Fig. 3B). Other measures or groups were not affected by bulbectomy. Prenatal MA exposure increased locomotion $\left[\mathrm{F}_{(1,56)}=4.03 ; \mathrm{p}<0.05\right]$, while decreasing immobility $\left[\mathrm{F}_{(1,56)}=5.40: \mathrm{p}<0.05\right]$.

Acute adult MA treatment increased locomotion $\left[\mathrm{F}_{(1,56)}=30.53 ; \mathrm{p}<0.0001\right]$ (Fig. 3A), rearing $\left[\mathrm{F}_{(1,56)}=38.36\right.$; $\mathrm{p}<0.0001]$, distance traveled $\left[\mathrm{F}_{(1,56)}=21.29 ; \mathrm{p}<0.0001\right]$ (Fig. 3C), average $\left[\mathrm{F}_{(1,56)}=21.29 ; \mathrm{p}<0.0001\right]$ (Fig. 3D) and maximal velocity $\left[\mathrm{F}_{(1,56)}=16.52 ; \mathrm{p}<0.001\right]$, while decreasing immobility $\left[\mathrm{F}_{(1,56)}=35.62 ; \mathrm{p}<0.0001\right]$ (Fig. 3B) and grooming $\left[\mathrm{F}_{(1,56)}=40.06 ; \mathrm{p}<0.0001\right]$. 

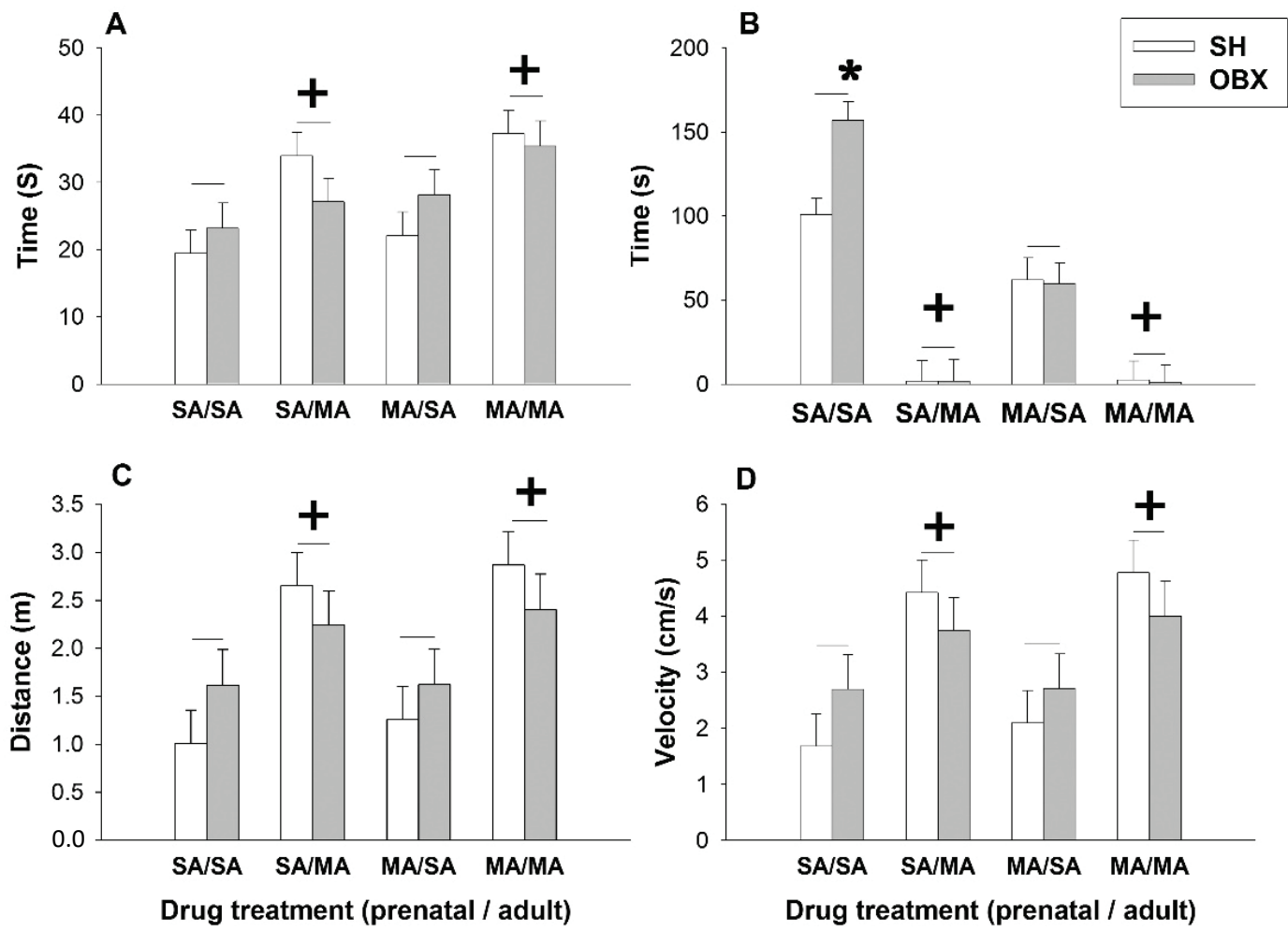

Fig. 3. The effect of maternal bulbectomy and drug exposure on locomotion (A), immobility (B), distance traveled (C) and average velocity (D) of adult offspring in LABORAS apparatus. $\mathrm{SH}=$ sham, $\mathrm{OBX}=$ bulbectomy. $\mathrm{SA}=$ saline, $\mathrm{MA}=$ methamphetamine. Values are mean \pm SEM $(n=8) ; * p<0.05$ sham-operated controls $(O B X>S H$ in SA/SA group, i.e. animals exposed both prenatally and postnatally to saline); ${ }^{+} p<0.05$ main effect: acute MA vs. acute saline.

\section{Discussion}

The aim of the present study was to extent our knowledge on the animals modelling of comorbid depression and addiction by evaluating developmental effects of combined MA exposure and depressive-like phenotype of the rat mothers induced by olfactory bulbectomy. As expected, OBX increased locomotion and decreased immobility in LABORAS apparatus, which is test used for rat behavior in novel environment. Enhanced locomotor activity reflects hyper-arousal of OBX animals as a response to a novel environment (Amchová et al. 2014, Flores et al. 2014, Holubová et al. 2016). Increased exploration in open field following OBX is one of the first reported behavioral changes evident as soon as 1 week after surgery (Hendriksen et al. 2015). Hyperactivity, as a consequence of novelty exposure, is probably caused by increased release of glutamate in the striatum (Ho et al. 2000). Increased level of glutamate was observed also in the nucleus accumbens shell, a reward-related brain area in the OBX rats (Rudá-Kučerová et al. 2015). It seems that glutamatergic system is largely distorted in the OBX model.

The present results demonstrated no differences in the maternal behavior as a matter of bulbectomy, with exception of prolonged sleeping time of OBX mothers relative to SH controls. In contrast to our results studies of others found that helplessness, as well as olfactory bulbectomy, as models of depression, decreases maternal behaviors, such as licking, grooming and nursing with arched-back position (Kurata et al. 2009, Sato et al. 2010). It should be however noted that most of these studies used mice to model the depressive-like phenotype (Neckers et al. 1975, Sato et al. 2010). In addition, there are studies showing that strain (Braw et al. 2009) as well as repeated pregnancy (Schwartz and Rowe 1976) may influence the impairing effect of depressive behavior on maternal behavior. In the present study primiparous albino Wistar rats provided by Charles River Laboratories International, Inc. were used. Using different species or strain of rodents might be the reason for no effect of OBX on maternal behavior observed in this experiment in the present study.

Even though this study did not show differences of bulbectomy on maternal behavior, there were some somatic as well as functional differences induced by bulbectomy of rat mothers in their offspring. Despite the fact that maternal weight did not differ, pups from OBX 
mothers were born with lower birthweight and gained less weight during the postnatal development than pups from SH controls. Further, both, OBX and prenatal MA administration, delayed the eyes opening. These OBX-induced effects are in line with a previous report showing similar somatic development in offspring of rat mothers subjected to chronic mild stress before fertilization (Cankara et al. 2012) which is a recognized model of depression (Micale et al. 2013). Similarly, offspring of rats who underwent the chronic mild stress during pregnancy exhibit attenuated prepulse inhibition of the startle reaction in adulthood which indicated higher anxiety (Holubová et al. 2016, Hougaard et al. 2011, Kjaer et al. 2010). Therefore, it seems that maternal stress per se may be able to induce long-lasting behavioral alterations on the offspring. The OBX animals have higher corticosterone levels as reported previously (Yang et al. 2014) which could be one of the factors contributing to the offspring development.

However, no additive effect of OBX and MA exposure was observed. As a matter of functional development of the pups, maternal OBX procedure impaired the performance in the Bar-holding test, but only in saline group. OBX/SA group was the worst in the Bar-holding test relative to all the other groups. The finding that maternal OBX impaired the performance of pups in Bar-holding test only in pups of mothers treated in gestation with saline but not in mothers treated with MA, suggests that MA somehow masked or apparently diminished the effect of OBX. In addition, pups from OBX mothers dropped more boluses during the Bar-holding test, suggesting that they were more vulnerable to stress. This is in line with the increased anxiety in the offspring of chronically stressed rats (Hougaard et al. 2011, Kjaer et al. 2010). Our present data also confirm the clinical findings that maternal depression is associated with impaired neurodevelopment in newborns (Smith et al. 2012). To the best of our knowledge there are no experimental studies showing the effect on maternal bulbectomy on pup's development. Furthermore, there are studies showing that maternal separation impairs postnatal development of rat pups (Secoli and Teixeira 1998, Zimmerberg et al. 2003). Because maternal separation, as a social isolation stress, produces depressive-like behavior of rat mothers (Boccia et al. 2007), these studies may also confirm our results. However, our data indicate that depressive-like phenotype is able to impair pup development even in the presence of standard maternal behaviors.
In adult male offspring, the assessment of locomotor activity showed mainly the stimulating effect of MA. Challenge dose of MA in adulthood increased distance traveled, locomotion, rearing, and average and maximal velocity, while decreasing immobility and grooming. This result confirms findings of others as well as our previous results showing increased locomotion after acute MA treatment that is associated with increased dopamine levels in rats (Bubeníková-Valešová et al. 2009, Jones et al. 2007, Šírová et al. 2016). In addition, the present results show novel results demonstrating that adult male rats from OBX mothers with no MA exposure displayed increased immobility. Interestingly, this effect of bulbectomy was not apparent in adult rats exposed to MA. The possible explanation of the absence of this phenomenon after the MA-challenge may lie in the relative non-specificity of the locomotor test together with pronounced behavioral response to MA. MA may have masked any subtle behavioral change induced by the OBX in the mother. As shown in the model of the maternal chronic mild stress (Hougaard et al. 2011, Kjaer et al. 2010) the offspring may exhibit mainly increased anxiety, which is difficult to be assessed by locomotion. Importantly, our data indicate a higher anxiety level in the Bar-holding test in the offspring of the OBX mothers. We suspect that a more complex evaluation of behavioral profile in the male offspring of the OBX mothers using paradigms sensitive for anxiety level assessment (e.g. Elevated plus maze, Ultrasonic vocalizations, etc.) may provide a better evidence of the developmental effects of maternal OBX procedure. Our previous studies (Macúchová et al. 2016, Pometlová et al. 2016, Šlamberová et al. 2015) described the specificity of the commonly used anxiety tests.

\section{Conclusions}

This study showed that depressive-like phenotype of rat mothers induced by olfactory bulbectomy led to impairment in somatic and functional development of their offspring in the absence of impaired maternal care. Similarly as in a clinical trial combining maternal depression and MA taking during gestation, no evidence of aggravation of the prenatal MA-induced deficits was observed in the offspring of mothers with olfactory bulbectomy.

\section{Conflict of Interest}

There is no conflict of interest. 


\section{Acknowledgements}

This study was supported by projects GAUK 850317, Progres Q35 and 260388/SVV/2017 provided by Charles University and the project MUNI/A/1063/2016 with the support of the Specific University Research Grant provided by the Ministry of Education, Youth and Sports of the Czech Republic in the year 2017. The procedures for animal experimentation utilized in this report was reviewed and approved by the Institutional Animal Care and Use Committee and is in agreement with the Czech Government Requirements under the Policy of Humans Care of Laboratory Animals (No. 246/1992) and with the regulations of the Ministry of Agriculture of the Czech Republic (No. 311/1997).

\section{References}

ALTMAN J, SUDARSHAN K: Postnatal development of locomotion in the laboratory rat. Anim Behav 23: 896-920, 1975.

AMCHOVÁ P, KUČEROVÁ J, GIUGLIANO V, BABINSKÁ Z, ZANDA MT, SCHERMA M, DUŠEK L, FADDA P, MICALE V, ŠULCOVÁ A, ET AL.: Enhanced self-administration of the CB1 receptor agonist WIN55,212-2 in olfactory bulbectomized rats: evaluation of possible serotonergic and dopaminergic underlying mechanisms. Front Pharmacol 5: 44, 2014.

BABINSKÁ Z, RUDÁ-KUČEROVÁ J, AMCHOVÁ P, MERHAUTOVÁ J, DUŠEK L, ŠULCOVÁ A: Olfactory bulbectomy increases reinstatement of methamphetamine seeking after a forced abstinence in rats. Behav Brain Res 297: 20-27, 2016.

BABINSKÁ Z, RUDÁ-KUČEROVÁ J: Differential characteristics of ketamine addiction in the olfactory bulbectomy model of depression in rats. Exp Clin Psychopharmacol 25: 84-93, 2017.

BAICY K, BEARDEN CE, MONTEROSSO J, BRODY AL, ISAACSON AJ, LONDON ED: Common substrates of dysphoria in stimulant drug abuse and primary depression: therapeutic targets. Int Rev Neurobiol 65: 117-145, 2005.

BOCCIA ML, RAZZOLI M, VADLAMUDI SP, TRUMBULL W, CALEFFIE C, PEDERSEN CA: Repeated long separations from pups produce depression-like behavior in rat mothers. Psychoneuroendocrinology 32: 65-71, 2007.

BRAW Y, MALKESMAN O, MERENLENDER A, DAGAN M, BERCOVICH A, LAVI-AVNON Y, WELLER A: Divergent maternal behavioral patterns in two genetic animal models of depression. Physiol Behav 96: 209-217, 2009.

BUBENÍKOVÁ-VALEŠOVÁ V, KAČER P, SYSLOVÁ K, RAMBOUSEK L, JANOVSKÝ M, SCHUTOVÁ B, HRUBÁ L, ŠLAMBEROVÁ R: Prenatal methamphetamine exposure affects the mesolimbic dopaminergic system and behavior in adult offspring. Int J Dev Neurosci 27: 525-530, 2009.

CANKARA N, DESDICIOGLU K, EVCIL EH, MALAS MA: The impact of prefertilization chronic mild stress on postnatal morphometric development. J Matern Fetal Neonatal Med 25: 165-173, 2012.

FILIP M, FRANKOWSKA M, JASTRZEBSKA J, WYDRA K, PRZEGALINSKI E: Preclinical studies on comorbidity between depression and psychostimulant addiction. Pharmacol Rep 65: 1529-1534, 2013.

FLORES G, IBANEZ-SANDOVAL O, SILVA-GOMEZ AB, CAMACHO-ABREGO I, RODRIGUEZ-MORENO A, MORALES-MEDINA JC: Neonatal olfactory bulbectomy enhances locomotor activity, exploratory behavior and binding of NMDA receptors in pre-pubertal rats. Neuroscience 259: 84-93, 2014.

GERALD MC, GUPTA TK: The effects of amphetamine isomers on rotarod performance. Psychopharmacology (Berl) 55: 83-86, 1977.

HALL DH, QUEENER JE: Self-medication hypothesis of substance use: testing Khantzian's updated theory. J Psychoactive Drugs 39: 151-158, 2007.

HENDRIKSEN H, KORTE SM, OLIVIER B, OOSTING RS: The olfactory bulbectomy model in mice and rat: one story or two tails? Eur J Pharmacol 753: 105-113, 2015.

HO YJ, CHANG YC, LIU TM, TAI MY, WONG CS, TSAI YF: Striatal glutamate release during novelty exposureinduced hyperactivity in olfactory bulbectomized rats. Neurosci Lett 287: 117-120, 2000. 
HOLUBOVÁ A, ŠTOFKOVÁ A, JURČOVIČOVÁ J, ŠLAMBEROVÁ R: The effect of neonatal maternal stress on plasma levels of adrenocorticotropic hormone, corticosterone, leptin, and ghrelin in adult male rats exposed to acute heterotypic stressor. Physiol Res 65 (Suppl 5): S557-S566, 2016.

HOLUBOVÁ K, KLETEČKOVÁ L, ŠKURLOVÁ M, ŘÍČNÝ J, STUCHLÍK A, VALEŠ K: Rapamycin blocks the antidepressant effect of ketamine in task-dependent manner. Psychopharmacology (Berl) 233: 2077-2097, 2016.

HOUGAARD KS, MANDRUP KR, KJAER SL, BOGH IB, ROSENBERG R, WEGENER G: Gestational chronic mild stress: effects on acoustic startle in male offspring of rats. Int J Dev Neurosci 29: 495-500, 2011.

JONES CD, BARTEE JA, LEITE-BROWNING ML, BLACKSHEAR MA: Methamphetamine-induced locomotor activity and behavioral sensitization: are dopamine d3 receptors involved? Cell Mol Biol (Noisy-le-grand) 53: 15-22, 2007.

KELLY JP, WRYNN AS, LEONARD BE: The olfactory bulbectomized rat as a model of depression: an update. Pharmacol Ther 74: 299-316, 1997.

KHANTZIAN EJ: Addiction as a self-regulation disorder and the role of self-medication. Addiction 108: 668-669, 2013.

KJAER SL, WEGENER G, ROSENBERG R, LUND SP, HOUGAARD KS: Prenatal and adult stress interplay-behavioral implications. Brain Res 1320: 106-113, 2010.

KOSTEN TR, MARKOU A, KOOB GF: Depression and stimulant dependence: neurobiology and pharmacotherapy. J Nerv Ment Dis 186: 737-745, 1998.

KUČEROVÁ J, PISTOVČÁKOVÁ J, VRŠKOVÁ D, DUŠEK L, ŠULCOVÁ A: The effects of methamphetamine selfadministration on behavioural sensitization in the olfactory bulbectomy rat model of depression. Int J Neuropsychopharmacol 15: 1503-1511, 2012.

KURATA A, MORINOBU S, FUCHIKAMI M, YAMAMOTO S, YAMAWAKI S: Maternal postpartum learned helplessness (LH) affects maternal care by dams and responses to the LH test in adolescent offspring. Horm Behav 56: 112-120, 2009.

MACÚCHOVÁ E, ŠEVČÍKOVÁ M, HREBÍČKOVÁ I, NOHEJLOVÁ K, ŠLAMBEROVÁ R: How various drugs affect anxiety-related behavior in male and female rats prenatally exposed to methamphetamine. Int $J$ Dev Neurosci 51: 1-11, 2016.

MALINOVÁ-ŠEVČÍKOVÁ M, HREBÍČKOVÁ I, MACÚCHOVÁ E, NOVÁ E, POMETLOVÁ M, ŠLAMBEROVÁ $\mathrm{R}$ : Differences in maternal behavior and development of their pups depend on the time of methamphetamine exposure during gestation period. Physiol Res 63 (Suppl 4): S559-S572, 2014.

MARKOU A, KOSTEN TR, KOOB GF: Neurobiological similarities in depression and drug dependence: a self-medication hypothesis. Neuropsychopharmacology 18: 135-174, 1998.

MCDONNELL-DOWLING K, KELLY JP: The consequences of prenatal and/or postnatal methamphetamine exposure on neonatal development and behaviour in rat offspring. Int J Dev Neurosci 47: 147-156, 2015.

MCKERNAN LC, NASH MR, GOTTDIENER WH, ANDERSON SE, LAMBERT WE, CARR ER: Further evidence of self-medication: personality factors influencing drug choice in substance use disorders. Psychodyn Psychiatry 43: 243-275, 2015.

MCKETIN R, LUBMAN DI, LEE NM, ROSS JE, SLADE TN: Major depression among methamphetamine users entering drug treatment programs. Med J Aust 195: S51-S55, 2011.

MICALE V, KUČEROVÁ J, ŠULCOVÁ A: Leading compounds for the validation of animal models of psychopathology. Cell Tissue Res 354: 309-330, 2013.

MORALES-MEDINA JC, IANNITTI T, FREEMAN A, CALDWELL HK: The olfactory bulbectomized rat as a model of depression: The hippocampal pathway. Behav Brain Res 317: 562-575, 2017.

MURPHY MP, RICK JT, MILGRAM NW, IVY GO: A simple and rapid test of sensorimotor function in the aged rat. Neurobiol Learn Mem 64: 181-186, 1995.

NECKERS LM, ZARROW MX, MYERS MM, DENENBERG VH: Influence of olfactory bulbectomy and the serotonergic system upon intermale aggression and maternal behavior in the mouse. Pharmacol Biochem Behav 3: 545-550, 1975. 
POMETLOVÁ M, YAMAMOTOVÁ A, NOHEJLOVÁ K, ŠLAMBEROVÁ R: Can anxiety tested in the elevated plusmaze be related to nociception sensitivity in adult male rats? Prague Med Rep 117: 185-197, 2016.

RIPER H, ANDERSSON G, HUNTER SB, DE WIT J, BERKING M, CUIJPERS P: Treatment of comorbid alcohol use disorders and depression with cognitive-behavioural therapy and motivational interviewing: a meta-analysis. Addiction 109: 394-406, 2014.

ROTHMAN RB, BAUMANN MH: Balance between dopamine and serotonin release modulates behavioral effects of amphetamine-type drugs. Ann N Y Acad Sci 1074: 245-260, 2006.

RUDÁ-KUČEROVÁ J, AMCHOVÁ P, HAVLÍČKOVÁ T, JEŘÁBEK P, BABINSKÁ Z, KAČER P, SYSLOVÁ K, ŠULCOVÁ A, ŠUSTKOVÁ-FIŠEROVÁ M: Reward related neurotransmitter changes in a model of depression: An in vivo microdialysis study. World J Biol Psychiatry 16: 521-535, 2015.

SATO A, NAKAGAWASAI O, TAN-NO K, ONOGI H, NIIJIMA F, TADANO T: Effect of non-selective dopaminergic receptor agonist on disrupted maternal behavior in olfactory bulbectomized mice. Behav Brain Res 210: 251-256, 2010.

SECOLI SR, TEIXEIRA NA: Chronic prenatal stress affects development and behavioral depression in rats. Stress 2: 273-280, 1998.

SCHUTOVÁ B, HRUBÁ L, ROKYTA R, ŠLAMBEROVÁ R: Gender differences in behavioral changes elicited by prenatal methamphetamine exposure and application of the same drug in adulthood. Dev Psychobiol 55: 232-242, 2013.

SCHWARTZ E, ROWE FA: Olfactory bulbectomy: influences on maternal behavior in primiparous and multiparous rats. Physiol Behav 17: 879-883, 1976.

SMITH LM, PAZ MS, LAGASSE LL, DERAUF C, NEWMAN E, SHAH R, ARRIA A, HUESTIS MA, HANING W, STRAUSS A, ET AL.: Maternal depression and prenatal exposure to methamphetamine: neurodevelopmental findings from the infant development, environment, and lifestyle (ideal) study. Depress Anxiety 29: 515-522, 2012.

SONG C, LEONARD BE: The olfactory bulbectomised rat as a model of depression. Neurosci Biobehav Rev 29: 627-647, 2005.

ŠEVČÍKOVÁ M, HREBÍČKOVÁ I, MACÚCHOVÁ E, ŠLAMBEROVÁ R: The influence of methamphetamine on maternal behavior and development of the pups during the neonatal period. Int J Dev Neurosci 59: 37-46, 2017.

ŠÍROVÁ J, KRIŠTOFÍKOVÁ Z, VRAJOVÁ M, FUJÁKOVÁ-LIPSKI M, ŘIIPOVÁ D, KLASCHKA J, ŠLAMBEROVÁ R: Sex-dependent changes in striatal dopamine transport in preadolescent rats exposed prenatally and/or postnatally to methamphetamine. Neurochem Res 41: 1911-1923, 2016.

ŠLAMBEROVÁ R, CHAROUSOVÁ P, POMETLOVÁ M: Methamphetamine administration during gestation impairs maternal behavior. Dev Psychobiol 46: 57-65, 2005.

ŠLAMBEROVÁ R, POMETLOVÁ M, CHAROUSOVÁ P: Postnatal development of rat pups is altered by prenatal methamphetamine exposure. Prog Neuropsychopharmacol Biol Psychiatry 30: 82-88, 2006.

ŠLAMBEROVÁ R: Drugs in pregnancy: the effects on mother and her progeny. Physiol Res 61 (Suppl 1): S123-S135, 2012.

ŠLAMBEROVÁ R, POMETLOVÁ M, MACÚCHOVÁ E, NOHEJLOVÁ K, STUCHLÍK A, VALEŠ K: Do the effects of prenatal exposure and acute treatment of methamphetamine on anxiety vary depending on the animal model used? Behav Brain Res 292: 361-369, 2015.

VOLKOW ND: The reality of comorbidity: depression and drug abuse. Biol Psychiatry 56: 714-717, 2004.

WOULDES TA, LAGASSE LL, HUESTIS MA, DELLAGROTTA S, DANSEREAU LM, LESTER BM: Prenatal methamphetamine exposure and neurodevelopmental outcomes in children from 1 to 3 years. Neurotoxicol Teratol 42: 77-84, 2014.

YANG SJ, YU HY, KANG DY, MA ZQ, QU R, FU Q, MA SP: Antidepressant-like effects of salidroside on olfactory bulbectomy-induced pro-inflammatory cytokine production and hyperactivity of HPA axis in rats. Pharmacol Biochem Behav 124: 451-457, 2014.

ZIMMERBERG B, ROSENTHAL AJ, STARK AC: Neonatal social isolation alters both maternal and pup behaviors in rats. Dev Psychobiol 42: 52-63, 2003. 